\title{
POÉTICA DE EUGÊNIO DE ANDRADE: ESPAÇO DA (RE)CONFIGURAÇÃO DO SER
}

\author{
POETICS OF EUGENIO DE ANDRADE: \\ SPACE RECONFIGURATION OF BEING
}

Amanda Aparecida Rodrigueiro*

\section{RESUMO}

Com base no contexto cultural em que a poética cria seu próprio sentido de representar o real através da reconquista e autonomia da linguagem, propõe-se discutir os recursos linguísticos da poética de Eugênio de Andrade, que reiteram alguns parâmetros críticos da nova poesia lírica, no sentido de reconfiguração do ser. Pautando-se em breves discussões da crítica acerca do subjetivismo anacrônico que demonstra a multiplicidade de vozes individuais, inseridas no sistema literário, na contemporaneidade, pretende-se também fazer uma reflexão sobre a construção poética eugeniana,, trazendo à tona algumas questões da poética moderna como, por exemplo, a noção de crise e a subjetivação e as transfigurações do ser. E, por fim, discutir o processo lingüístico peculiar do poeta que vislumbra essas questões humanas, intemporais, por meio de um arranjo bastante particular, a ponto de a crítica literária não inserir sua produção em nenhuma corrente específica, muito embora seja dono de vasta produção literária entre 1940 e 2000.

PALAVRAS-CHAVE: Eugênio de Andrade. Espaço. Revelação do ser. 


\section{ABSTRACT}

Based on the cultural context in which poetry creates its own sense of representing the real through the reconquers and autonomy of language, it is proposed to discuss the linguistic features of the poetics of Eugênio de Andrade, that reiterate some critical parameters of the new lyric poetry in the sense of being reset. And are based on brief critique of discussions about the anachronistic subjectivism which shows the multiplicity of individual voices, set in the literary system, in contemporary times, also is intended to reflect on the poetic construction eugeniana, bringing up questions of modern poetry as, for example, the notion of crisis and the subjectivity and the transfiguration of being. Finally, discuss the peculiar linguistic process of the poet who sees these human, timeless issues through a very particular arrangement, the point of literary criticism not enter production in any particular chain, even though it is owned vast production literature between 1940 and 2000.

KEY WORDS: Eugênio de Andrade. Space. Configuration of being.

\section{CONSIDERAÇÕES INICIAIS}

A poesia de Eugênio de Andrade, poeta português conhecido pelo retrato do homem e da vida, inseridos na paisagem natural elementar, revela a busca constante da reconstrução humana no espaço poemático. Esse espaço produzido e transmutado pela e na linguagem pode suscitar não só uma experiência representativa da própria construção da linguagem poética, mas, sobretudo, vislumbrar reflexões acerca da subjetividade e da identidade humana, questões pertinentes à crítica moderna e pósmodernas. Sob essa perspectiva de estudo, objetiva-se discutir de que forma o espaço, permeado pelos elementos naturais, presente nos poemas de Eugênio de Andrade, corporifica a natureza humana, essencialmente espacial (enquanto integrada à natureza), reificada pela e na linguagem poética. Averiguar, ainda, a partir de recursos linguísticos presentes nos poemas, questões referentes à subjetivação postas à tona, num caminho percorrido pela poética moderna e à crise da subjetivação, segundo a pósmodernidade.

A proposta de reflexão sobre as questões subjetivas e identitárias, perpassadas pelas imagens espaciais presentes nos poemas eugenianos, embasa-se em discussões sobre o espaço poético, os estudos da retórica e estilística, o papel do leitor, entre outras orientações da crítica sobre a escrita do poeta, bem como sobre afirmações sobre a crítica moderna e contemporânea.

Para a realização deste estudo sobre a busca constante da reconstrução humana no espaço poemático presente na poesia de Eugênio de Andrade, uma breve leitura interpretativa dos poemas: "Noite transfigurada", "Elegia, Três ou quatro sílabas" e "Ao fim da tarde", será apresentada. 


\section{PRECEITOS DA LITERATURA MODERNA-CONTEMPORÂNEA}

O uso da linguagem contemporânea surge no cenário da literatura significativamente, no que diz respeito à poesia nova, marcada por um contexto de transformações socioculturais, políticas e econômicas. Para compreender a problemática da atual produção poética faz-se necessário resgatar a idéia do modernismo como um movimento de ruptura e destruição dos valores do passado e que lutou pela estética do novo pelo novo. Indaga-se, a partir daí, as características estéticas que compõem a nova poesia, exemplificando com poemas selecionados de Eugênio de Andrade, que resgatam o anacronismo e a singularização que a originalidade poética requer quanto ao uso da linguagem que, através desses novos parâmetros, provoca o efeito da verdade para se identificar com o leitor.

O moderno, segundo Octavio Paz (1984, p.18), não é caracterizado como uma novidade ou uma continuidade do passado no presente, pois apresenta uma estética heterogênea como forma de ruptura. A tradição heterogênea vinculou as mais diversas vozes poéticas para tornar o moderno autossuficiente e fundar a tradição, pois não houve uma manifestação literária sem a negação desse passado. De acordo com Hegel (2004, p.155), o pensamento romântico trouxe para a poética moderna o ideal da lírica como essencialmente subjetiva. Dessa maneira, o poeta passou a manifestar sua experiência individual, separando o sujeito lírico da objetividade das coisas para se refugiar no próprio espírito. Com isso, o eu lírico passou a expressar não apenas a realidade das coisas em si, mas o modo que afetam a interioridade.

Em Portugal, o surgimento do modernismo literário propõe a ideia de criar uma arte cosmopolita no tempo e no espaço que, em Fernando Pessoa, é desnacionalizada e acumula dentro de si todas as partes do mundo. Assim, a poesia lírica moderna portuguesa objetivou a proposta do novo de romper com o status quo literário (passado), implantando um sujeito lírico fragmentado que retratasse a realidade.

Posteriormente, o Presencismo retomou o conservadorismo no nível estético e no plano ideológico, o psicologismo, a busca do eu profundo, o individualismo e a evasão dos problemas sociais. Propondo uma literatura neutra, mais voltada para a temática universalizante e intemporal.

A afirmação de Amaral (1991) acerca da modernidade corrobora a idéia de que o que o modernismo emergiu de uma crise estabelecida na relação do homem com o mundo moderno: “(...) equivale a um conceito razoavelmente consensual de crise, de uma imagem congruente do homem e do mundo, o que irá levar a uma literatura dessubjetivizada em que o criador se transforma num não-eu" (AMARAL, 1991, p.39).

Desse modo, o mundo fragmentado passou a ser representado por uma arte poética inovadora, no sentido de buscar a autonomia da linguagem através da perda de estabilidade do indivíduo. Tal sujeito foi incapaz de representar mimeticamente a realidade e a poesia lírica não teve ou- 
tra finalidade senão a constituição da palavra poética. Entretanto, a estética da ruptura cede lugar ao aparecimento de uma época com uma diversidade de poetas de estilos diferentes, chamada de contemporâneo.

Segundo Cruz (2003), a poesia lírica portuguesa na década de 70 e 80 apresenta uma espécie de mosaico fluido, com uma geração de poetas que se destacaram pela individualidade de suas obras literárias. Esses escritores detiveram-se não só na escolha dos paradigmas para a criação poética, bem como na discussão de uma arte marcada pela crise dos valores sociopolíticos e culturais. Apesar da forte presença da pluralidade poética na nova poesia, muitos poetas apresentaram algumas características comuns: a diminuição representativa da realidade vista a partir de uma crise mimética e o resgate da linguagem e do sentido com caráter lírico.

Segundo Agamben (2009, p.62) o poeta contemporâneo é aquele que, ao mesmo tempo, mantém o olhar fixo no seu tempo, sustentando uma relação singular com o presente, distancia-se dele e aponta as diferenças para compreender as formas de ser e estar no mundo. Todavia, não são contemporâneos os poetas que coincidem de modo absoluto com a época sem a visão do passado, pois não conseguem manter o olhar fixo no seu tempo. $\mathrm{O}$ anacronismo não conduz o retorno da mesma coisa, mas direciona a uma interação interpretativa que produz algo novo, com uma sequência de pensamentos que dá origem à outra coisa em uma incorreta organização temporal de ideias, pessoas ou acontecimentos.

O mundo contemporâneo aparece em um contexto cultural de pluralidade de vozes poéticas em que a obra de arte passou a ter uma enorme carga de subjetividade. A lírica criou o seu sentido anacrônico de representar o real através da reconquista e da autonomia da linguagem. É, pois, sob essa pluralidade caleidoscópica de vertentes poéticas, que a poesia eugeniana está inserida num patamar bastante singular, que busca a (re) figuração humana por meio da palavra transfiguradora de imagens elementares do homem e da vida.

\section{A POÉtICA DE EUGÊNIO DE ANDRADE: ESPAÇO DE PLENITUDE E (RE) SUBJETIVAÇÃO DO SER}

Segundo a crítica especializada a poesia de Eugênio de Andrade vincula-se a busca da plenitude da vida. Assim a palavra/poesia é libertadora, porque cria/localiza a realidade (permeada pelos quatro elementos), mediadora entre o homem e as coisas. E o poeta, na busca de viver, tem na palavra a imagem mais concreta do seu desejo.

Eduardo Lourenço (1996, p.117, 119-120) assevera que na poesia eugeniana a busca da vida no que ela tem de mais puro e feliz reside na idéia da sua plenitude em relação à morte, no que diz respeito aos contínuos ciclos da vida, que a fazem eterna. E diante dessa constatação, não há angústia na sua poesia, mas serenidade ou, pelo menos, a sua busca. fazer 
poético é quem possibilita a "posse feliz do mundo e de si mesmo". Eis a grandiosidade da poesia, "a conciliação impensável e, todavia, existente da nossa realidade e do nosso sonho, por palavras que miraculosamente, dizem o indizível". E, por conseguinte, "o poema aparece, como o lugar da unidade humana reencontrada", embora fragilmente.

De acordo com Lourenço (1996), a poesia cria a realidade por meio da palavra. Nesse sentido, a palavra é a própria realidade mediadora entre os homens e as coisas. Isto é, a palavra é o espaço onde o homem se configura como tal. E sob essa perspectiva, a linguagem é senhora do homem. Ao poeta, cabe apoderar-se dela e criar a realidade que está além da nossa humanidade e da existência das coisas, pois só somos o que somos pela palavra.

A poesia de Eugênio de Andrade exprime, justamente, esse movimento máximo da palavra-cristal, cria a realidade na qual nos insere por meio da palavra:

Parece haver uma estranha desproporção entre a matéria frágil que nos transfigura, poema, quadro ou sinfonia, essa vertiginosa metamorfose da existência humana. [...] Através deles se cumpre o mais fabuloso e paradoxal milagre: tornamo-nos no que já somos (LOURENÇO, 1996, p.127).

No que diz respeito à produção eugeniana, Lopes (s/d) alega ser a sua poesia um manancial de imagens diversas, que confluem a um mesmo lugar, um paraíso terrestre, onde a palavra, severamente escolhida ao movimento da metáfora, vislumbra a integração dos quatro elementos. Constitui o que ele nomeia de um imagismo português calcado nas referências materiais, e que não deixa à deriva tudo que é poesia: o corpo, os sentidos, as raízes sociais envoltos numa emoção frásica, mediada por uma linguagem referencial, mas movendo-se sempre da referência real. Resultam dessa articulação as próprias imagens elementares, que assumem valores espaciais de posições muito diversas.

Embora a crítica caracterize a poesia de Eugênio de Andrade pela importância atribuída à palavra, tanto pelo valor imagético, quanto pela temática da figuração do homem que se integra ao espaço natural, composto pelos quatro elementos, esta proposta de leitura, conduzida pelo viés da recepção, pode não considerar todos os aspectos discutidos pela crítica, uma vez que a produção de sentido se constrói por meio de um diálogo contínuo entre texto, contexto e leitor.

Quanto à teoria espacial vinculada à poesia, há estudos que discutem a assimilação dessa categoria narrativa pela poesia; contudo, sua articulação e significação apresentam-se de maneira distinta à do texto narrativo. Santos e Oliveira (2001) afirmam, por exemplo, que a imagem e o cenário apresentam-se, na poesia, como forma efetiva de revelação lírica.

Segundo Santos e Oliveira (2001), embora o espaço situe a personagem/eu-lírico, sua significação se diferencia no texto narrativo e poé- 
tico. Na narrativa, o espaço é intrínseco à composição textual interna. $\mathrm{Na}$ poesia, contudo, ele pode ser explorado pelo uso imagético da palavra, não vislumbrando, necessariamente, a estrutura interna do texto:

Nas narrativas literárias, o espaço tende a estar associado a referências internas ao plano ficcional mesmo que a partir desse plano sejam estabelecidas relações com espaços extratextuais. [...]. O texto poético pode eleger a própria palavra como um espaço: O signo verbal não é apenas decodificado intelectualmente, mas também sentido em sua concretude. Sobretudo, é possível explorar na poesia escrita, a visualidade da palavra: o signo verbal como imagem. (SANTOS e OLIVEIRA, 2001, p.74).

Blanchot (1987), ao estudar o espaço enquanto construção literária exige certa solidão do leitor que, na construção linguística, o poeta se cala, para fazer ecoar no seu texto imagens com um significado profundo ao leitor:

A obra não é acabada nem inacabada: ela é. [...]. Aquele que vive na dependência da obra, seja para escrevê-la, seja para lê-la, pertence à solidão do que só a palavra ser exprime: palavra a linguagem obriga dissimulando-a ou faz aparecer quando se oculta no vazio silencioso da obra. (BLANCHOT, 1987, p.12).

Em consonância ao elucidado por Lourenço (1996): dizer o indizível, por meio do fazer poético, tendo o poema como lugar da unidade humana reencontrada, Blanchot (1987) afirma ser o papel do poeta, ouvir a linguagem ininteligível e, pelo desvio, espacializá-la no poema de modo a intermediar as significações produzidas pelo leitor. Ou seja, o espaço, com seu status transformador e transcendental, promove a interiorização dos elementos, possibilitando a formação de um espaço imaginário:

No mundo, as coisas são transformadas em objetos a fim de serem apreendidas, utilizadas, tornadas mais seguras, na firmeza distinta de seus limites e na afirmação de um espaço homogêneo e divisível - mas, no espaço imaginário, transformadas no inapreensível, nos introduz sem reserva num espaço onde nada nos retêm. [...] o espaço interior "traduz as coisas". Fá-las passar de uma linguagem para outra, da linguagem exterior para uma totalmente interior. O espaço [que] nos supera e [que] traduz as coisas é, portanto, o transfigurador, o tradutor por excelência. (BLANCHOT, 1987, P.139)

Quanto ao papel desempenhado pela literatura, segundo Blanchot (1987), o poeta se isola do mundo por sua capacidade artística de fazer versos e pela necessidade de exilar-se no imaginário, tomando consciência de que não tem outra morada a não ser o espaço das imagens poéticas. Assim, a arte cumpre seu papel de manifestar-se pela imagem a verdade inalcançável.

Heidegger (2004), ao estudar a relação espaço/homem, parte da 
ideia de interioridade, delimitando a presença do homem na medida em que ele e os elementos que o circundam são dados pelo espaço. Cria-se um espaço homogêneo, no qual estão inseridos ser humano e cenário. Entretanto, cabe ao homem dar existência relevante aos elementos espaciais pela proximidade estabelecida com eles. No sentido de o objeto funcionar como seu instrumento, ao olhá-lo, atribui-lhe existência e torna-o próximo de si: "espacial, a presença existe segundo o modo da descoberta do espaço inerente à circunvisão, no sentido de se relacionar num contínuo distanciamento com os entes que lhe vêm ao encontro no espaço". (HEIDEGGER, 2004, p.157)

O homem, nesse sentido, sendo um ser espacial, relaciona-se com o mundo circundante por meio do distanciamento e da direcionalidade. O distanciamento ocorre por meio da proximidade, ou seja, ao se aproximar de determinado elemento espacial o ser se distancia de outro que, nesse momento, desaparece por não estar em contato com o mesmo. O direcionamento, porém, é próprio do distanciamento, porque ao distanciar-se de alguns elementos o ser precisa direcionar-se a outros para lhes atribuir existência através da aproximação direcionada. Segundo as afirmações de Heidegger (2004) pode-se vislumbrar o homem como um ser no espaço, conferindo ou não valor de existência aos elementos espaciais que o circundam. Essa contribuição, entretanto, não avança para o modo como o homem estabelece relação com o cenário que o circunda, atribuindo-lhe valores e interagindo com eles.

A afirmação de Lourenço (s/d, p.37) sobre o status poesia (sobretudo, da poética eugeniana) vem de encontro aos preceitos da modernidade e pós-modernidade, quando afirma ser ela o impronunciável que paradoxalmente se pronuncia, deixando intacta a essencial incomunicabilidade de tudo. O poema aparece como o lugar da unidade humana reencontrada, mas como é um lugar de palavras, essa morada é frágil, "um eterno morrer e devir corrompe a palavra poética, assim como o poeta/homem, sua criatura e criador. A palavra não é exterior ao homem, mas seu núcleo frágil e ardente. Por isso a poesia é o homem na busca do seu nome, da sua realidade. Porque só a palavra poética revela o abismo que nos separa da unidade, a busca da unidade humana no presente submerso e inacessível da palavra-total. Pela palavra o poeta reivindica o milagre de uma plenitude que ele sabe ausente e que dessa ausência se expressa.

Coelho (s/d, p.67) afirma que Eugênio de Andrade traz a marca essencial da modernidade e a ruptura da tradição representativa em que o poema conceberia uma realidade anterior a ele. O poema na sua transparência é o próprio espaço, que não deixa ver nada através dele, porque reafirma que tudo está nele.

Outro aspecto frequente na poética eugeniana, segundo Coelho (s/d, p.73), é a irradiação do humano. Há uma equivalência entre todos os 
elementos do mundo, por meio da não-fixação dos significantes em relação aos significados, numa dialética do sistema de significantes. Essa afirmação corrobora a posição moderna citada pela crítica de que o modernismo literário propõe a ideia de criar uma arte cosmopolita que desnacionalizada acumula em si todas as partes do mundo.

Coelho (s/d, p.83-85), ao discutir a poética eugeniana, afirma que há repetição incessante do drama eu/tu, sendo o "eu" apagado (uma leve marca) e o "tu" é aquele que passa, e só no poema eles se encontram brevemente. Nesse sentido, aborda uma questão crucial da literatura moderna, discutida por Amaral (1991): a dessubjetivação em que o criador se transforma num não-eu. Entretanto, pode-se falar que em Eugênio de Andrade não há um apagamento do "eu", mas um esmaecimento por uma idiossincrasia pela qual o "tu" sempre tem superioridade ao "eu", que ocupa um lugar discreto no poema. Na relação eu/tu, há quase ausência de interioridade, existindo mais jogos de corpos e palavras.

Sob o viés da discussão da (des/re) subjetivação na poesia eugeniana, Mendonça (s/d, p.111), ao afirmar o caráter adâmico e supra-real de sua poética, dialoga com o que Cruz (2003) explica sobre a diminuição representativa da realidade, a partir de uma crise mimética, o resgate da linguagem e do sentido com caráter lírico estão presentes na poética moderna. Para Mendonça (s/d), Andrade resgata o poder adâmico das palavras, quando busca seu emblema absoluto, ao usá-las antes do seu significado corrompido, por isso, pela poesia, retorna ao $\mathrm{Pa}$ raíso, onde tudo é antes de ser. Daí advém a pureza buscada pela e na poesia, onde há pureza das coisas sem nome, na sua essência absoluta ainda não nomeada (onde as coisas são anteriores ao seu significado). O poeta resgata a pureza original, o sentido primeiro, busca seu emblema absoluto, antes de terem nome cotidiano, instaura o poder de usar as coisas sem nome ou em situações incomuns, como por exemplo: "Acordar não é triste, nem alegre, é ser rosa”.

A poética de Eugênio de Andrade, então se aproxima da supra-realidade não só porque confere novos valores de realidade ao ser das vivências, mas, sobretudo, porque está aquém dela, "Suas palavras configuram-se como alotropismos que vão além de tempo e do espaço e se reformulam expansivamente, regressam ao âmago do ser e das coisas e as reconfiguram buscando sua realidade primeira, que foge ao cotidiano (Mendonça, s/d).

É, pois, apresentando a leitura de poemas selecionados, quanto ao status do eu e da linguagem, que se observa o lugar singular que ocupa a poética eugeniana, no panorama da produção literária portuguesa moderna e pós-moderna, ao promover a (re) configuração do ser, por meio de figurações que remetem ao "paraíso", à integração/diluição do ser no cosmos, na natureza elementar, no outro, pelo poder da palavra adâmica que instaura um eterno devir das coisas e do ser na construção de si. 


\title{
POEMAS DE EUGÊNIO DE ANDRADE: QUESTÕES HUMANAS (MODERNAS/PÓS) E A (RE) CONFIGURAÇÃO DO HOMEM
}

O poema "Noite transfigurada", da obra As mãos e os frutos (1948), possui uma composição formal livre, estruturando-se em três estrofes, compostas por oito, seis e sete versos heterométricos (livres), com variação de duas a dez sílabas poéticas, versos brancos e rimas alternadas consoantes: "embalada/transfigurada/madrugada" e toantes "descidas/esquinas".

Noite transfigurada

Criança adormecida, ó minha noite, noite perfeita e embalada

como as folhas,

noite transfigurada,

ó noite mais pequena do que as fontes,

pura alucinação da madrugada

_chegaste,

nem eu sei de que horizontes.

\author{
Hoje vens ao meu encontro \\ nimbada de astros, \\ alta e despida \\ de soluços e lágrimas e gritos \\ _ó minha noite, namorada \\ de vagabundos e aflitos. \\ Chegaste, noite minha, \\ de pálpebras descidas; \\ leve no ar que respiramos, \\ nítida no ângulo das esquinas \\ _ó noite mais pequena do que a morte: \\ nas mãos abertas onde me fechaste \\ ponho os meus versos e a própria sorte. \\ (ANDRADE apud SARAIVA, 1999, p.30).
}

O poema refere-se à noite, idéia evidenciada a partir do título que, metaforicamente, transfigura-se verso a verso, personificando-se em seres e sentimentos: "criança adormecida"; "alucinação da madrugada", antitética e gradativamente oscilam entre a alegria e a tristeza. As metáforas indicativas dessas transformações remetem aos quatro elementos: a terra representada pelas palavras "folhas, horizontes, pálpebras, esquinas"; a água é referendada pelos vocábulos "fontes e lágrimas"; o fogo, pelos "astros" e o ar, no seu sentido próprio.

Inicialmente, por meio da hipálage "criança adormecida", a noite é adjetivada como frágil, inocente e perfeita. Posteriormente, ainda na primeira estrofe, a marca da fonte em "- ó noite mais pequena do que as fontes / pura alucinação da madrugada” pode remeter à idéia de nascimento/ vida, que são maiores do que a noite (sofrimento, tristeza) e na madrugada, quase se acaba para receber a luz do dia, sugerindo alegria. Entretanto, os 
versos “-chegaste / nem eu sei de que horizontes" remetem ao tom de surpresa com que o eu lírico vê a noite.

A segunda estrofe reverbera o tom melancólico, mas não triste que acompanha a transfiguração da noite. Aos poucos, cada adjetivo oscila entre um tom soturno, melancólico e outro mais esperançoso, alegre: "nimbada de astros / alta e despida de soluços e lágrimas e gritos / ó minha noite, namorada/de vagabundos e aflitos".

É na terceira estrofe que o eu lírico decide-se pelo tom dado à "sua" noite (no poema há a anáfora "minha noite", remetendo, metaforicamente, aos sentimentos do eu lírico): angustiante, mas, no entanto, classifica tudo isso como menor do que a morte, e, numa atitude corajosa entrega seus versos e seu destino, afinal tem a consciência de que tanto a vida quanto a morte são certas: "nítida no ângulo das esquinas /_ó noite mais pequena do que a morte", numa atitude de sempre exaltação da vida que se sobrepõe à morte, quando cumpre o seu ciclo.

A noite aparece como interlocutora do eu lírico que, constantemente, a invoca "ó noite", vislumbrando um monólogo que revela o homem na busca de uma reflexão sobre a vida. Sob o viés da estilística e da retórica, o poema é construído num movimento de metáforas, que corroboram o próprio título e revelam as transfigurações da noite (dos sentimentos) pelas palavras que pouco a pouco (folha a folha) e, dialeticamente, modificam-se: "noite perfeita versus alucinação da madrugada" / "nimbada de astros versus despida de soluços", "leve no ar versus nítida nas esquinas". O plano morfossintático reverbera o semântico, na medida em que as palavras oscilam entre a angústia e a esperança. No final, nenhum sentimento ganha, posto que diante de uma força paradoxal da noite "nas mãos abertas onde me fechaste", o "eu" aceita tais forças da vida, serenamente.

A "noite", entendida como metáfora da palavra (escrita poética), transfigura-se em seres e sentimentos bons e ruins, diluída no movimento da vida, não há como fugir disso. Assim, fica o sentido (provocado no leitor, segundo Iser) de que o jogo dialético das forças que regem a vida assemelha-se aos jogos de palavras poéticas, causando angústia, mas também podendo ser visto com tranquilidade, ao se considerar a inevitabilidade dos acontecimentos e das palavras, aos quais estamos sujeitos nas transfigurações da vida. Evidencia-se o sentido de plenitude que reside na poesia eugeniana, na busca constante da serenidade, da irmandade com a vida para que o homem alcance a felicidade no encontro com ele mesmo.

O poema "Noite transfigurada" ilustra o que Lourenço (s/d) alega sobre o status da poesia eugeniana, nos preceitos da modernidade. Atribui às palavras o poder de unidade humana, possível apenas nesse movimento contínuo do eterno morrer e do devir. Paradoxalmente, reivindica o milagre da plenitude que se faz ausente e, ao mesmo tempo, é seu "motor" expressivo: “Chegaste, noite minha, / nítida no ângulo das esquinas/_ó noite mais pequena do que a morte:/ nas mãos abertas onde me fechaste/ ponho os meus versos e a própria sorte". 
Da obra Amantes sem dinheiro (1950), o poema "Elegia" é composto por cinco quintetos, de versos heterométricos de quatro e doze sílabas poéticas, sendo a maioria constituída por versos mais longos. Há rimas emparelhadas, interpoladas (ABCCB/DEFFE), toantes e consoantes: "havia/harmonia"; "plenitude/juventude".

Elegia

Ás vezes era bom que tu viesses.

Falavas de tudo com modos naturais:

em ti havia

a harmonia

dos frutos e dos animais.

Maio trouxe cravos como outrora,

cravos morenos, como tu dizias,

mas cada hora

passa e não se demora

na tristeza das nossas alegrias.

Ainda sabemos cantar,

só a nossa voz é que mudou:

somos agora mais lentos,

mais amargos,

um novo gesto é igual ao que passou.

Um verso já não é maravilha, um corpo já não é a plenitude, tu quebraste ritmo, $\mathrm{o}$ ardor, ao partires um a um

os ramos todos da tua juventude.

Não estamos sós:

setembro traz ainda

um fruto em cada mão.

Mas os homens, as aves e os ventos

já não bebem em ti a direção.

(ANDRADE apud SARAIVA, 1999, p. 40).

"Elegia" é uma composição lírica que lamenta com profunda tristeza os acontecimentos dolorosos, ao referir-se à melancolia. O eu lírico, num tom abatido, recorda o tempo passado, nos verbos "havia", "trouxe", "mudou", "passou". A partir da segunda estrofe, a ideia de tristeza, gradativamente, ganha força. Esse sentimento articula-se à ideia de tempo que passa, reiterado pelos verbos, na sua maioria, no pretérito imperfeito e, no presente. Os substantivos marcam as estações do ano "maio" e "setembro", além das palavras "hora", "demora", "agora" e "outrora", que reforçam a passagem temporal. Sob essa perspectiva, o poema se estrutura, retoricamente, em dois momentos distintos.

Os sete primeiros versos remetem às lembranças passadas e significativas que relembram momentos de plenitude da vida: "Às vezes era 
bom que tu viesses/ Falavas de tudo com modos naturais: em ti havia/ a harmonia/ dos frutos e dos animais". A ideia é reforçada pelos advérbios "às vezes" e pelo adjetivo "bom", reiterada pelos substantivos "harmonia" e "maio" que, por sua vez, remetem à alegria, juventude da vida e à primavera que renova a natureza, ao referir-se aos "cravos morenos". No entanto, a conjunção "mas" rompe com o passado harmônico. Do verso oitavo até o final do poema, o eu lírico revela sua melancolia diante do tempo que passa. A ruptura temática é reiterada pela introdução da adversativa (mas), e a mudança do tempo verbal. Assim, no segundo momento do texto, vislumbra-se um paradoxo que indica o conflito alegria/tristeza: "na tristeza das nossas alegrias", mas o sentimento que se instala é a tristeza/melancolia, reforçada por adjetivos negativos intensificados por advérbios "mais lentos", "mais amargos", por paralelismos negativos "Um verso já não é a maravilha/ um corpo já não é a plenitude”.

A ideia de melancolia cresce, gradativamente, perante a construção linguística, que mostra mais um rompimento na sintaxe, na semântica e na sonoridade do poema, com o verso "tu quebraste o ritmo, o ardor". O tempo que passa é o responsável pela melancolia, uma vez que faz perder o "ardor", os "ramos da juventude", com a chegada da velhice, também anunciada pelo outono que chega (o mês de setembro). Nos versos finais, há uma oscilação entre a esperança e a melancolia: o outono ainda traz a vida simbolizada "um fruto em cada mão". Porém, nos dois últimos versos, a adversativa "mas" em consonância à negativa "não" volta a reforçar a angústia do eu lírico (metáfora de sua obra) diante da nova realidade da vida: "Mas os homens, as aves, e os ventos /já não bebem em ti a direção".

A esperança que passa à melancolia e à angústia pode ser reiterada, no plano sonoro, pela aliteração das sibilantes e assonância das vogais "o" e "i", lembrando um sussurro de lamento. Assim, a musicalidade se configura, nesse poema, a partir do plano fono-semântico, uma vez que a idéia de música inicia-se com o título "Elegia", ressaltada por outros vocábulos: cantar, voz e ritmo, e reverberada pelas repetições sonoras: rimas, aliterações, períodos longos que evidenciam um ritmo monótono e contínuo, como a própria elegia lembra num tom de desabafo triste.

Nota-se que o uso do pronome "tu" é, na verdade, um recurso estilístico usado pelo poeta (como fizera em outros poemas), que revela a proposta de um "voltar-se para si", numa atitude reflexiva. Essa transfiguração do "eu" em "tu" ilustra a afirmação de Coelho (s/d, p.83-85) sobre a presença, em Andrade, da repetição incessante do drama eu/tu, sendo o "eu" apagado (é uma leve marca) e o "tu" é aquele que passa. Reverbera a afirmação de Amaral (1991) acerca da dessubjetivação, entretanto, não há no poema o apagamento do eu, mas seu arrefecimento em detrimento do "tu", um subterfúgio para revelar uma ausência de interioridade, na busca de si. Ou seja, no jogo de corpos e palavras, o "eu" busca (re) figurar-se: Um verso já não é maravilha, /um corpo já não é a plenitude, /tu quebraste ritmo, o ardor, /ao partires um a um/os ramos todos da tua juventude. /Não 
estamos sós:/setembro traz ainda/um fruto em cada mão. /Mas os homens, as aves e os ventos/já não bebem em ti a direção.

Os quatro elementos da natureza são constantes na poesia de Eugênio de Andrade, no "retrato" que faz do homem e da vida. No poema "Elegia" estão presentes a terra, simbolizada pelos vocábulos frutos, animais, cravos, ramos e mão; o ar, nas metáforas "aves" e "ventos"; o fogo, revelado pelo substantivo "ardor" e a água, subentendida pelo verbo "bebem". A presença dos elementos na poesia reforça a idéia da busca da comunhão do homem com a natureza e seu ciclo (o tempo passa). A vida é revelada pelo poder da palavra poética eugeniana.

Observa-se que toda a construção poemática revela a melancolia do eu-lírico, mas em relação a quê? A resposta pauta-se em algumas leituras possíveis: a melancolia cantada pode ser em relação à consciência do tempo que passa e com ele, o homem envelhece, restando apenas os momentos lembrados. Ou, num plano mais metafórico, pode-se entender que a angústia do eu-lírico advém da consciência de que como a vida e o homem, a palavra também passa; "Um verso já não é a maravilha/ Mas os homens, as aves e os vento/ já não bebem em ti a direção".

No que diz respeito ao efeito de sentido causado pela leitura e pelas estruturas textuais, a sensação de desalento vislumbrada pelo leitor na escrita configura-se desde o título, confirmando-se na adjetivação expressiva, na sonoridade das vogais fechadas e no poder verbo-visual das palavras.

Da obra Véspera da Água (1973), o poema “Três ou quatro sílabas" é composto de três quadras não rimadas. Os versos são livres e metrificados entre quatro e treze sílabas poéticas. Os versos mais longos e a ausência de rimas dão um tom mais seco e menos ritmado ao poema, cuja temática envolve a presença da morte, num tom quase melancólico que deixa de ser, a partir da força atribuída à palavra.

Três ou quatro sílabas

Neste país

onde se morre de coração inacabado deixarei apenas três ou quatro sílabas de cal viva junto à água.

É só o que me resta

e o bosque inocente do teu peito meu tresloucado e doce e frágil

pássaro das areias apagadas.

Que estranho ofício o meu procurar rente ao chão uma folha entre a poeira e o sono húmida ainda do primeiro sol. (ANDRADE apud SARAIVA, 1999, p. 98). 
O poema "Três ou quatro sílabas", inicialmente, remete ao ofício da escrita. Apresenta um sentimento triste, instigado pela presença da morte, "onde se morre de coração inacabado", "só o que me resta", "estranho ofício". Entretanto, essa ideia ou sentimento inicial é convertido, quase que miraculosamente, no último verso, pelo poder da palavra poética. Quando todas as palavras vêm, num movimento crescente, ligadas ao desabafo diante da morte, no último instante surge, pelas palavras, a luz da vida, na sua força total.

Esse poema revela um recurso estilístico-retórico usado pelo poeta em algumas obras, a surpresa dos versos finais, numa virada metafórica. Observe-se o movimento metafórico, usado num sentido retórico de modo a persuadir sobre a grande idéia do poema: a vida permanece incólume à morte, pela força viva dada às palavras: "Que estranho ofício o meu/ procurar rente ao chão/ uma folha entre a poeira e o sono/ húmida ainda do primeiro sol".

O ofício falsamente modesto de buscar na materialidade (rente ao chão), ou nos elementos mais simples, que passam despercebidos e se acabam na sua finitude, (a folha entre a poeira e o sono), a imortalidade grandiosa da vida ("folha húmida ainda do primeiro sol"), a palavra-folha impregnada de luz. A integração do homem à natureza acontece, indiretamente, via palavra, que é buscada na folha banhada de sol, e que ficará junto à água, se o homem for avaliado como uma metáfora do próprio discurso que produz.

A presença da morte, na poesia de Eugênio é, muitas vezes, um simples limite à luminosidade vital e ligada à imagem serena da água. Essa ideia pode ser vista, nessa poesia, quando o eu-lírico registra "deixar sua palavra na cal viva junto à água”. A presença dos elementos intrinsecamente ligados ao homem presentifica-se em toda a obra de Eugênio de Andrade.

Quanto ao efeito causado no leitor, pode-se afirmar que "três ou quatro sílabas" exprimem a vultosa força da palavra literária: reitera a vida, no seu sentido mais amplo, porque faz viver à medida que provoca sentimentos e/ou reflexões, as mais profundas possíveis que, muitas vezes, não podem ser tão bem traduzidas, senão pela linguagem poética: eis o sumo poder de "três ou quatro sílabas", exalam vida e grudam n’alma; não morrem jamais!.

"Três ou quatro sílabas" resgatam o poder adâmico das palavras, segundo Mendonça (s/d), quando o eu lírico com seu "estranho ofício" procura "rente ao chão/ uma folha entre a poeira e o sono/ húmida ainda do primeiro sol", busca a pureza das coisas sem nome, na sua essência absoluta e em seu sentido primeiro e absoluto.

O poema "Ao fim da tarde", pertencente à obra Pequeno Formato (1997). Trata-se de um terceto unistrófico (quase um haicai) pautado no elemento água, através da figura do mar: 
Ao fim da tarde

Ninguém esperava ver o mar naquele dia mas era o mar que estava ali à porta naqueles olhos.

(ANDRADE apud SARAIVA, 1999, p. 189).

A partir do título, apresenta a ideia do tempo que passa, ou um ciclo que se cumpriu. Assim, o primeiro verso, através do pretérito imperfeito, sugere a ideia da morte, que chega como o fim da tarde. Contudo, ninguém a esperava da forma como ela se apresentou: "mas era o mar que estava ali". No fim da vida não se espera vê-la, mas o eu lírico revela um momento único, por uma linguagem plástica, a imagem concreta de uns olhos-mar. Isto é, por meio de um movimento metafórico, a morte vista por um olhar cheio de vida: diante da presença da morte o que se via eram uns olhos cheios de vida, cheios de mar.

"Ao fim da tarde" rompe com a tradição representativa, ao trazer uma realidade anterior a ele, que não se deixa ver nada além do que está posto na sua transparência, o poema é o lugar que abriga todas as coisas e a não-fixação dos significantes em relação aos significados, traz uma equivalência entre todos os elementos do mudo, só possível no espaço poético. (COELHO, s/d, p.67,73). Assim é que "o mar" pode estar presente "à porta" de uns "olhos".

Observa-se nesse poema de curta extensão, o uso da palavra árida, densa e "pesada", uma a uma, no sentido de presentificar a imagem da vida, de modo despojado, a fim de, ao final, permanecer somente a palavra-realidade, no que ela tem de concreta: a vivacidade emanada de uns olhos. E, a partir da leitura dessa palavra econômica, contudo, precisa, o efeito causado é da vida que, na palavra, adquire total concretude, a ponto de justificar a afirmação de Candido sobre o poder humanizador da Literatura:

Dado que a Literatura, como a vida, ensina na medida em que atua com toda a sua gama [...] ela age com o impacto indiscriminado da própria vida [...], como altos e baixos, luzes e sombras [...] Ela não corrompe nem edifica, portanto; mas, trazendo livremente em si o que chamamos bem e o que chamamos o mal, humaniza em sentido profundo, porque faz viver (CANDIDO, 1972, p. 805-806).

No decorrer da leitura dos poemas de Eugênio de Andrade, o leitor certifica-se que o poeta, na palavra articulada, considera a vida mais intensa quanto mais densa é a palavra que a profere. É o êxtase, ou o efeito estético promulgado por Jauss (1994): "a experiência denominada "primária" de qualquer obra de arte realiza-se com o seu efeito estético -Einstellung auf - constituído de compreensão fruidora e de fruição compreensiva”. É sentir-se em comunhão com a vida, com o universo, sentir-se amplo, integrado ao cosmos. É doloroso sentir que a palavra utilitária não consegue revelar a emoção suscitada pela palavra-luz de Eugênio de Andrade. 


\section{CONSIDERAÇÕES FINAIS}

Realizada a leitura interpretativa dos poemas de Eugênio de Andrade, com o objetivo de discutir como o espaço neles se presentifica e em que medida contribui para a descoberta do homem de si próprio, através da palavra poética, pode-se afirmar que o espaço poético reitera a natureza humana ao integrar o homem aos elementos naturais que o corporificam, na e pela poesia. É, pois, no poema, que a palavra adquire o status de lugar onde o homem se faz homem, por meio do movimento de metáforas que suscitam imagens concretas da vida plena no seu movimento dialético de transformação e, do homem que vive essa plenitude, (re) dimensionando-se a cada palavra. Isto é, por meio da palavra poética configurada pelos elementos naturais, realidades humanas são promovidas a cada leitura; realidades que remetem à integração do indivíduo ao universo, revelando-lhe o conhecimento de si. Como propõe a lírica contemporânea, com uma reinterpretação da subjetividade lírica por meio do mundo exterior, projetando "um sujeito fora de si" (COLLOT, 2004, p.166).

Ressalta-se, principalmente, o esmero da palavra poética eugeniana, reveladora da humanidade do homem, no que ele tem de mais simples e complexo: sua materialidade corporal, reiterada pelos quatro elementos (água, ar, terra e fogo) e pela palavra (o discurso poético) que o constitui enquanto ser pensante, "sentinte", por isso mesmo, vivente. A proposta poética do autor, nesse sentido, contribui para a (re) constituição do imaginário humano à medida que revigora a força dada à palavra tanto pelo seu valor imagético quanto pela simplicidade e concretude espacial com a qual anuncia a vida plena de sentidos, onde o homem se (re) encontra, constantemente. A palavra poética configurada pelos elementos naturais (elementos de coesão), realidades humanas, são instigadas a cada leitura. Realidades que remetem à integração do indivíduo ao universo, revelando-lhe o conhecimento de si.

Conclui-se que a poesia eugeniana traz a (re) subjetivação do ser, que, muitas vezes, passa por uma espécie de dessubjetivação, não do apagamento total do eu, um esmaecimento, adquirindo um novo status do eu, ora transfigurado ou apenas imbricado ao cosmos nos elementos naturais. Ora esmaecido no outro, pelo sentimento do amor e do desejo, mas sempre (re) figurado, pela palavra cristal, transfigurada pela emblemática do absoluto.

Nesse sentido, pode-se reafirmar que a poética de Eugênio de Andrade ocupa um patamar singular no panorama da produção literária portuguesa moderna e pós-moderna, ao promover a (re) configuração do ser, por meio de figurações que remetem ao "paraíso", à integração/ diluição do ser no cosmos, na natureza elementar, no outro, pelo poder da palavra adâmica que instaura um eterno devir das coisas e do ser na construção de si próprio. 


\section{REFERÊNCIAS BIBLIOGRÁFICAS}

AGAMBEN, Giorgio. O que é contemporâneo? e outros ensaios. Tradutor Vinícius Nicastro Honesko. Chapecó, Santa Catarina: Argos, 2009.

AGUIAR e SILVA, Vítor Manuel. Teoria e Metodologia Literária. Lisboa: Universidade Aberta, 1990.

AMARAL, Fernando Pinto do. Modernismo, Modernidade e suas consequências: um percurso por alguma poesia portuguesa deste século. In: Mosaico fluido: Modernidade e pós-modernidade na poesia portuguesa mais recente (autores revelados na década de 70). Lisboa: Assírio \& Alvim, 1991.

ANDRADE, Eugênio. Eugénio de Andrade: seleção, estudo e notas de Arnaldo Saraiva. Rio de Janeiro: Nova Fronteira, 1999.

BLANCHOT, Maurice. O espaço literário. Trad. CABRAL, A. Rio de Janeiro: Rocco, 1987.

CANDIDO, Antônio. A literatura e a formação do homem. Ciência e Cultura, v.24, n.9, 1972.

_. O estudo analítico do poema. São Paulo: FFLCH-USP, 1993.

COELHO, Eduardo Prado. "Relatório duma leitura da poesia de Eugênio de Andrade, e do prazernque ela provoca no leitor". LOPES, Oscar (org.). 21 ensaios sobre Eugênio de Andrade. Porto: Inova, s/d.

COLLOT, Michel. O sujeito lírico fora de si. In: Terceira Margem. Poesia brasileira e seus encontros interventivos. Rio de Janeiro, $\mathrm{n}^{\circ}$. 11, p.165177, 2004.

CRUZ, Gastão. Nova poesia e poesia nova. In: Relâmpago Nova poesia portuguesa. Revista de Poesia. Lisboa: Fundação Luis Miguel Nava, n. 12, p.19-37, 2003.

HEGEL, Georg Wilhelm Friedrich. Cursos de estética. Volume IV. Tradução de Marco Aurélio Werle e Oliver Tolle. São Paulo: EDUSP, 2004.

HEIDEGGER, Martin. Ser e Tempo. Parte 1. Trad. SCKUBACK, M. S. C. 13 ed. São Francisco: Vozes, 2004.

PAZ, Octavio. A tradição da ruptura. A revolta do futuro. In: Os filhos do barro: do romantismo à vanguarda. Tradução de Olga Savary. Rio de Janeiro: Nova Fronteira, 1984.

LOPES, Oscar. 21 ensaios sobre Eugênio de Andrade. Porto: Inova, s/d.

LOPES, Oscar. \& SARAIVA, Arnaldo José. História da Literatura Portuguesa. 16 ed. Portugal: Editora Porto, s/d.

LOURENÇO, Eduardo. "A poesia de Eugênio de Andrade". LOPES, Oscar (org.). 21 ensaios sobre Eugênio de Andrade. Porto: Inova, s/d. 
O espelho imaginário. Imprensa Nacional-Casa da Moeda,

1996.

. Tempo e Poesia. Lisboa: Relógio d'água, 1996.

MENDONÇA, Fernando. "Eugênio de Andrade ou a emblemática do real absoluto”. LOPES, Oscar (org.). 21 ensaios sobre Eugênio de Andrade. Porto: Inova, s/d.

SANTIAGO, Silviano. A permanência do discurso da tradição no Modernismo. In: Nas malhas da letra. Ensaios. São Paulo: Companhia das Letras, 1989.

SANTOS, Luís Alberto Brandão. \& OLIVEIRA, Silvana Pessoa. Sujeito, tempo e espaços ficcionais: Introdução a teoria da literatura. São Paulo: Martins Fontes, 2001.

Recebido para publicação em 31/05/2015

Aprovado em 28/08/2015

\section{NOTAS}

* Graduação em Letras pela Universidade Estadual de Maringá (1996), Especialização em Literatura e Ensino (UEM- 2001), Mestrado em Letras (UEM - 2006), com enfoque em Literatura Portuguesa, cujo tema é a poética elementar e imagética de Eugênio de Andrade. Atualmente é professora da rede estadual de ensino do Estado do Paraná e é doutoranda do PLE - UEM, cuja pesquisa enfoca o espaço enquanto revelação lírica, na poética de Eugênio de Andrade. 